\title{
Executive Financial Compensation And Organizational Resilience Of Deposit Money Banks In Rivers State, Nigeria
}

\author{
OGA, Kelechi Charles *, EVWIERHURHOMA, Ejiroghene Daniel ${ }^{\text {** }}$ \\ ${ }^{*}$ PhD Student, Department of Management, Faculty of Management Sciences, University of Port Harcourt, Nigeria. \\ ** PhD Student, Department of Management, Faculty of Management Sciences, University of Port Harcourt, Nigeria. \\ DOI: 10.29322/IJSRP.10.12.2020.p10807 \\ http://dx.doi.org/10.29322/IJSRP.10.12.2020.p10807
}

\begin{abstract}
The purpose of this paper is to examine the relationship between executive financial compensation and organizational resilience of Deposit Money Banks in Rivers State, Nigeria. The predictor variable is executive financial compensation which was used as a uni-dimensional variable while the criterion variable: organizational resilience has three measures vis-à-vis adaptive capacity, situational awareness and innovation. The study adopted a correlational and cross-sectional research design and uses questionnaire as the research instrument which was distributed to 57 top executives of 19 DMBs operating in Rivers State which comprises of 3 executives from each DMBs. The data generated were analyzed through the use of Spearman's Rank Order Correlation Coefficient as well as t-statistics to test the relationship between the variables of the study through the use of Statistical Package for Social Sciences within a significance level of 0.05 . The findings showed that executive financial compensation has positive and significant effect on organizational resilience vis-à-vis adaptive capacity, situational awareness and innovation of DMBs in Rivers State respectively. We therefore recommend among others that DMBs should apply effective and efficient executive financial compensation to motivate their executives so as to withstand environmental threats.
\end{abstract}

Index Terms- Executive Financial Compensation; Organizational Resilience; Adaptive Capacity; Situational Awareness; Innovation

\section{INTRODUCTION}

$\mathrm{T}$ he business environment Deposit Money Banks (DMBs) found themselves has today become so complicated, uncertain as well as more volatile than before, as such today's strategy that yield enhanced performance might become obsolete as well as miss the set target overnight. More so, the $21^{\text {st }}$ century organizations including the DMBs are faced with increased vulnerability because they are subject to more and unforeseeable risks due to globalization and rapid changes from the business environment that might hinder their ability to be successful. However, in the events of this rapid changes, most organizations are not prepared and have no plans to navigate through. Thus the lack of business continuity plans in today's organizations especially developing countries like Nigeria shows that most organizations are not well prepared for disruptive events such as changes in cultural practices, increasing competition, dynamics and environmental uncertainty. To explain further, Gabriel (2015) expressed that Nigerian organizations are scarcely prepared for challenges, especially in the wake of current sociopolitical and economic quandaries like the disruption brought about by "ENDSARS". Though the "ENDSARS" struggle in Nigeria was not initially meant to suffocate the economy until it was hijacked by hoodlums who went about disrupting business activities and injuring lots of peaceful protestant.

Business organizations that must survive in today's business environment must be resilient enough in its daily operations. In other words, organizations have to possess resilience as quality in order to be able to manage threats externally on their way to achieving their set objectives. Thus, Eketu and Ahiauzu (2015) expressed that the ability of an organization to succeed and survive is a function of its capacity to adapt to its environment continuously. Consequently, organizations that want to be prosperous and survive in nowadays dynamic and complex environment must be able to adapt to it. Seville, Porter and Askew (2008) expressed that given that environment of business cannot be wholly controlled, organizations must be resilient in their daily operations. Furthermore, the challenge for organizations in today's business environment is to build up capacities to respond continuously to changes in the environment. To attain this, organizations must of necessity engage more in executive compensation package such as financial compensation. This is because, in today's uncertain business environment with all its complexities, for organization to adapt, the organization needs higher effective and efficient compensation especially that of the executives. Based on the fact that, the executives are sets of organizations' human resources that are very strategic and essential to the success of the organization due to the role they play in ensuring the organization attain its goal(s).

Compensation provided to executives in organizations is very important to their motivation which provides the basis on how well the operations of the organization will be coordinated; this can provide the motivation that can facilitate resilience in the organization during emergency. Thus, if financial compensation is effectively given, executives will have the motivation to carry out their tasks effectively and efficiently which can provide the ability of the organization to bounce back during turbulence. The need to study the relationship between executive financial compensation and organizational resilience in today's business environment has 
become urgently needed due to frequent environmental changes that is affecting the performance of all organizations across the globe especially in the developing world. More so, studies (Sheffi, 2005; Mullich, 2009; Dewald \& Bowen, 2010; Wicker, Filo \& Cuskelly, 2013; Umoh, Amah \& Wokocha, 2014) on organizational resilience from extant literature especially in this part of the world has not looked in the direction of executive financial compensation in regards to organizational resilience. Thus, taking into consideration previous research on organizational resilience, there seems to be a lacuna on how financial executive compensation can influence organizational resilience. Therefore, this study abridged this gape through examining the role of executive financial compensation in enhancing organizational resilience vis-à-vis adaptive capacity, situation awareness and innovation of DMBs in Rivers State, Nigeria. This study would therefore be of great significance to managers of DMBs, in the sense that its outcome would have a significant policy implication for organizational success since the compensation of executives is an issue common to all organizations. It would further help organizations especially the DMBs in knowing the relationship that exist between executive financial compensation and organizational resilience.

\section{RESEARCH QUESTIONS}

The following are the research questions that guided this paper:

i. What is the relationship between executive financial compensation and adaptive capacity of DMBs in Rivers State, Nigeria?

ii. What is the relationship between executive financial compensation and situation awareness of DMBs in Rivers State, Nigeria?

iii. What is the relationship between executive financial compensation and innovation of DMBs in Rivers State, Nigeria?

\section{RESEARCH HYPOTHESES}

The following are the study research hypotheses stated in the null form:

$\mathrm{H}_{1}$ : There is no significant relationship between executive financial compensation and adaptive capacity of DMBs in Rivers State, Nigeria.

$\mathrm{HO}_{2}$ : There is no significant relationship between executive financial compensation and situation awareness of DMBs in Rivers State, Nigeria.

$\mathrm{H}_{3}$ : There is no significant relationship between executive financial compensation and innovation of DMBs in Rivers State, Nigeria.

\section{LITERATURE REVIEW}

\section{Theoretical Framework}

This paper is anchored on agency theory as its theoretical foundation. Agency theory focused on the relationships between the owners of a business (called principals) and the hired executives (called agents) (Jensen \& Meckling, 1997). The theory further expressed that for the organization to achieve set objectives, the principal must have a good relationship with the agent by ensuring that the agent do not seek self-gratifying interests rather than the interest of the organization's owners. This could be achieved by adequately providing regular compensation plans to managers as this would motivate them to attain greater efficiency levels, whereby reducing the occurrence of agency problem (conflict of interest) between managers and the business owners, fostering the maintenance of adequate financial reserves and the addition of value to the organization which might bring about the enhancement of organizational resilience in challenging times. Clearly, the executives of the organization, determines the level of productivity that will be attained and performance that will be achieved in the organization, thus, executives should be well compensated as it would energize and propel them to work harder towards attaining the organization's goal(s) in times of crisis.

\section{CONCEPT OF EXECUTIVE FINANCIAL COMPENSATION}

Compensation can be seen as a system of rewards that is capable of inspiring a worker to do more in a given task. In the view of Martocchio (2004) compensation has to do with intrinsic (psychological satisfaction) and extrinsic (monetary and nonmonetary) rewards given to employee. These psychological satisfaction and monetary reword energizes him or her to put more effort in making sure a given task is perform effectively and efficiently. More so, the concept of executive compensation represents intrinsic and extrinsic rewards given to an organization's top executives for job done. Thus, Junaidu and Sanni (2014) defined executive compensation as financial and non-financial awards given to the executives for services rendered to the organization. This includes of salary, bonuses, share benefits etc. In a more succinct way, executive compensation is the remuneration packages set aside for the top management of an organization which goes with executive labor services (Jegede, 2012; Bebchuk, Grinstein \& Peyer, 2010). Executive compensation is different from that of lower-level employees. This is because the salary and other benefits are negotiated and documented in a formalized employment contract (Heatfield, 2018). The contract contains all agreement and other special terms of employment. Executive compensation is negotiated between the potential executive and the employer. Non-executive compensation is similar among functional level employees under a standard remuneration (Heatfield, 2018). Thus, executive compensation, is negotiated and agreed upon in an employment contract. It includes substantial differences in benefits and salary different from the regular rewards by the organization.

Furthermore, executive financial compensation is the financial payments and non-monetary benefits provided to high level management in exchange for their work on behalf of an organization. It is a compensation that is concerned with monetary terms which comprises financial rewards and financial incentives provided to top executives of an organization. According to Armstrong (2003); Martocchio (2004) executive financial compensation provide financial recognition to top executives for attaining or exceeding their performance targets or reaching certain levels of competence or skill. It therefore, has to do with the act of providing top executives with money or other things of economic value in exchange for their labour or to provide for the costs of injuries that they have incurred in cause of carrying out 
their executive functions and it includes salary, bonuses, and merit based pay. Salary is a compensation paid to executives which can be fixed weekly, monthly, or annually. It is the remuneration to the services of the executives by the organization and it is a tool of payment in the form of currency. It includes the basic and the auxiliary pay. The basic pay is the foundation to determining various allowances, insurances and bonuses which depends on the following factors vis-à-vis labour's skills, work experiences, labor intensity, responsibility, work importance in the organization's strategy, work years etc. The auxiliary pay include allowances, free working meals, housing subsidies, etc. The payment of good salary is one of the strategies in motivating any human resource including the executives in order to enhance their performance, commitment and satisfaction. This is because it influences the workers' behaviour as well as attract, and increase the intention to stay and lead to organization's higher performance (Tella, Ayeni \& Popoola, 2007).

Bonus is the extra payment which is received as a reward by the executive for effectively and efficiently performing his or her job well. It usually comes along with salary of the executive. It is the gesture of appreciation from the organization towards their executives. It is not only given for the job well done but also to keep the employees vis-à-vis the executives motivated and focused. The distribution of bonus is completely depends upon the policies and profitability of the organization. The reason of the payment of bonus is basically to bridge the gap between the ideal of a living wage and the wages paid (Park \& Sturman, 2009). Merit based pay is a compensation program where basic pay increase are determined by individual performance, as opposed to across the board increases. According to Jensen (2014), merit- based pay play a vital role to bring job satisfaction, organizational commitment and job performance whereby most organization are using the merit based pay system as a strategic reward plan that can enhance the workers performance and influence the workers' working behaviour toward higher fulfillment with the organization.

\section{Organizational Resilience}

The unpredictable business environment makes business firms susceptible to risk emanating from the environment; thus organization must be resilient in its day to day operation in order to be able to withstand these changes. Thus, organizational resilience is the ability of an organization to respond rapidly to unforeseen changes, even chaotic disruption, pursue its goals despite disruption through mindfulness, agility, and consistency. It is a proclivity of an organization to attain a flexible quality in order to respond effectively to its environment as changes occur in it. Organizational resilience is more of the capacity of an organization to predict a changes or disruption and adapt to same as well as recovering quickly as much as possible from perturbation (Madni, 2007). It also has to do with the ability of the organization to be creative as well as having the enthusiastic to react quickly to the effect of unanticipated changes from the environment (Weick, Sutcliffe \& Kathleen, 2007). Hence, it is the ability of an organization to acclimatize during turbulence so as to maintain high performance. This definition suggests that organizations must be able to develop an adaptive capacity to mitigate the impact of negative environmental events as well as a bounce back, or rebound, to earlier levels of performance following a period of inferior performance or performance decline.

Furthermore, McManus, Seville, Vargo and Brundsdon (2008) expressed that the numerous concepts that emerge from definitions of organizational resilience include knowledge of the environment, level of preparation, anticipation of perturbations, adaptation, capacity to recover, etc. The ability of organizations to absorb shock or develop resistance in the face of turbulences and disruption within its environment is a reflection of how prepared the organization can be. According to Robb (2000), a resilient organization is able to sustain competitive advantage over time through its capability to do two things simultaneously; deliver excellent performance against current goals, and effectively innovate and adapt to rapid, turbulent changes in markets and technologies. The measures of organizational resilience used in this study include adaptive capacity, situation awareness and innovation discussed below:

Adaptive capacity has to do with the culture in the organization which allows the organization to make effective and efficient decisions on time as well as on daily basis in the face of crises (McManus et al., 2008). Adaptive capacity depends on the attributes of individuals, organizations and institutions that foster learning when faced with change and uncertainty, such as willingness to learn from mistakes, engage in collaborative decision-making arrangements, and encourage institutional diversity (Armitage, 2005). It include the ability of the organization to learn to live with uncertainty, combining various knowledge for learning and creating opportunities for selforganization. It is the engagement and involvement of organizational staff so that they are responsible, accountable and occupied with developing the organization's resilience through their work because they understand the links between the organization's resilience and its long term success.

Situation awareness has to do with the ability of the organization to have future projection of the environment and understand same from their current position. Endsley (1988) posits that situation awareness has to do with the ability of the organization to perceived elements in the environment within a volume of time and space, the comprehension of their meaning and a projection of their status in the near future. Thus, it is the mindful, vibrant and active thoughtfulness of the situation or changes in the environment an organization operates which gives the organization the capability to think of about the potentials that lie in the future and not necessarily focusing on the past (Bedny $\&$ Meister, 1999). The dynamic reflection contains logicalconceptual, imaginative, conscious and unconscious components which enables the organization to develop mental models of external events.

Innovation relates to seeking out unsatisfied needs and taking of strategic steps to create a new product or service that will become a solution to needs of the society. It has to do with the process of adding a new feature to a product or making a whole change to the product or the process involves in making a given product which bring about a new product or service that gives value or satisfy the needs of customers (Abdul \&Syeda, 2014). It therefore has to do with the ability of the organization to be creative (Damanpour, 1991). The ideal culture of innovation would include the willingness to cannibalize existing products, balanced marketing and technology ideation, embrace risk and 
focus on the future. The ability to innovate in times of difficulties and crisis is very important to ensuring the resiliency of the organization towards organizational succes (Tellis, 2013).

\section{Methodology}

We used correlational research design through crosssectional studies focused on top executives of DMBs in Rivers State in other to know the relationship that exist between executive financial compensation and organizational resilience. Consequently, research survey design was adopted using questionnaire as the research instrument which consist of four respond choices with 5 Point Likert scales ranging from 1 to 5 indicating strongly disagree, disagree, indifference, agree and strongly agree respectively. To ascertain the validity and reliability of the research instrument, we adopted face and content validity while the reliability of the instrument was done using Cronbach Alpha which showed a Cronbach Alpha value of 0.862 for executive financial compensation, 0.925 for adaptive capacity, 0.893 for situation awareness and 0.858 for innovation. The predictor variable is executive financial compensation and it is used as a uni-dimensional variable while the criterion variable is organizational resilience with three measures vis-à-vis adaptive capacity, situational awareness and innovation. The population of the study comprised of 57 top executives of 19 DMBs operating in Rivers State which comprises of 3 executives from each DMBs. Though, these DMBs have their Head offices in Lagos, they however have their regional offices in Rivers State and the executives ranges from General Managers (GM), Deputy General Managers (DGM), Assistant General Managers (AGM), Executive Directors (ED), Divisional Executives (DE), Principal Managers (PM), Zonal Managers (ZM). More so, all the 57 executives were also used as the sample size. Furthermore, out of the 57 questionnaires distributed 53 representing $92.98 \%$ were retrieved and were properly filled which were used for our analysis while the other $4(7.02 \%)$ questionnaire were not retrieved. Data gathered were analyzed through the use of Spearman's Rank Order Correlation Coefficient as well as t-statistics was used to test the relationship between the variables of the study through the use of Statistical Package for Social Sciences (SPSS) Windows version 25 within a significance level of 0.05 .

\section{DATA ANALYSIS AND RESULTS}

\section{The Strength of the Relationship between Executive Financial Compensation and Adaptive Capacity}

Table 1: Correlation between executive financial compensation and adaptive capacity

\begin{tabular}{|c|c|c|c|c|}
\hline & & & $\begin{array}{l}\text { Executive } \\
\text { Financial } \\
\text { Compensation }\end{array}$ & Adaptive Capacity \\
\hline \multirow[t]{6}{*}{ Spearman's rho } & Executive & FinancialCorrelation Coefficient & 1.000 & $.884^{* *}$ \\
\hline & Compensation & Sig. (2-tailed) & . & .000 \\
\hline & & $\mathrm{N}$ & 53 & 53 \\
\hline & Adaptive Capacity & Correlation Coefficient & $.884^{* *}$ & 1.000 \\
\hline & & Sig. (2-tailed) & .000 & . \\
\hline & & $\mathrm{N}$ & 53 & 53 \\
\hline
\end{tabular}

Source: SPSS v25: Output, 2020.

Table 1 reveals that a very strong and positive significant relationship exist between executive financial compensation and adaptive capacity with a $(r h o=0.884)$ and a PV $=0.000$ which is less than 0.05 . In other words positive relationship exists between the variables, thus, the provision of financial compensation to executives will provide adaptive capacity for the DMBs in Rivers State. The degree to which executive financial compensation influences adaptive capacity is further shown in the below table 2 :

Table 2: the degree of effect of executive financial compensation on adaptive capacity

\begin{tabular}{|c|c|c|c|c|}
\hline \multicolumn{5}{|c|}{ Model Summary } \\
\hline Model & $\mathrm{R}$ & R Square & Adjusted R Square & Std. Error of the Estimate \\
\hline 1 & $.884^{\mathrm{a}}$ & .781 & .802 & .38160 \\
\hline
\end{tabular}

Source: SPSS v25: Output, 2020

Table 2 above reveals the degree to which executive financial compensation influences adaptive capacity with R-val.= 0.884 which implies a very strong relationship while the $\mathrm{R}^{2}=0.781$ implies that executive financial compensation explain $78.1 \%$ variation in 
DMBs adaptive capacity while the remaining $21.9 \%$ could be due to the influence of other factors not included in this study. The relationship is further tested applying t-statistics as shown in Table 3 below:

Table 3: T-value result on executive financial compensation and adaptive capacity

\begin{tabular}{|c|c|c|c|c|c|c|}
\hline \multicolumn{7}{|c|}{ Coefficients $^{\mathbf{a}}$} \\
\hline \multirow{2}{*}{\multicolumn{2}{|c|}{ Model }} & \multicolumn{2}{|c|}{ Unstandardized Coefficients } & \multirow{2}{*}{$\begin{array}{l}\text { Standardized } \\
\text { Coefficients } \\
\text { Beta }\end{array}$} & \multirow[b]{2}{*}{$\mathrm{T}$} & \multirow[b]{2}{*}{ Sig. } \\
\hline & & $\mathrm{B}$ & Std. Error & & & \\
\hline \multirow[t]{2}{*}{1} & (Constant) & .756 & .539 & & 11.531 & .000 \\
\hline & $\begin{array}{l}\text { Executive } \\
\text { Compensation }\end{array}$ & Financial.701 & .472 & .630 & 8.057 & .000 \\
\hline
\end{tabular}

a. Dependent Variable: Adaptive Capacity

Source: SPSS v25: Output, 2020

From Table 1 , the PV $=0.000$ which is less than 0.05 and Table 3 shows $\beta=0.701 ; \mathrm{t}$-cal. $=8.057>\mathrm{t}-\mathrm{crit}$. $=1.96$ at $0.000<0.05 \%$ which means that the relationship between executive financial compensation and adaptive capacity is statistically significant. We therefore reject the null stated hypothesis and accept the alternate hypothesis, thus there is significant relationship between executive financial compensation and adaptive capacity of DMBs in Rivers State, Nigeria.

The Strength of the Relationship between Executive Financial Compensation and Situation Awareness

Table 4: Correlation between executive financial compensation and situation awareness

\begin{tabular}{|c|c|c|c|c|}
\hline & & & $\begin{array}{l}\text { Executive } \\
\text { Financial } \\
\text { Compensation }\end{array}$ & Situation Awareness \\
\hline \multirow[t]{6}{*}{ Spearman's rho } & Executive & FinancialCorrelation Coefficient & 1.000 & $.926^{* *}$ \\
\hline & Compensation & Sig. (2-tailed) & . & .000 \\
\hline & & $\mathrm{N}$ & 53 & 53 \\
\hline & Situation Awareness & Correlation Coefficient & $.926^{* *}$ & 1.000 \\
\hline & & Sig. (2-tailed) & .000 & . \\
\hline & & $\mathrm{N}$ & 53 & 53 \\
\hline
\end{tabular}

**. Correlation is significant at the 0.05 level (2-tailed).

Source: SPSS v25: Output, 2020.

Table 4 reveals that a very strong and positive significant relationship exist between executive financial compensation and situation awareness with a $(r h o=0.926)$ and a PV $=0.000$ which is less than 0.05 . In other words positive relationship exists between the variables, thus, the provision of financial compensation to executives will lead to situation awareness of the business environment of the DMBs in Rivers State. The degree to which executive financial compensation influences situation awareness is further shown in the below table 5:

Table 5: the degree of effect of executive financial compensation on situation awareness

\begin{tabular}{lllll}
\hline $\begin{array}{l}\text { Model Summary } \\
\text { Model }\end{array}$ & R & R Square & Adjusted R Square & Std. Error of the Estimate \\
\hline 1 & $.926^{\mathrm{a}}$ & .857 & .839 & .45023 \\
\hline
\end{tabular}

a. Predictors: (Constant), Executive Financial Compensation

Source: SPSS v25: Output, 2020

Table 5 above reveals the degree to which executive financial compensation influences situation awareness with R-val.= 0.926 which implies a very strong relationship while the $\mathrm{R}^{2}=0.857$ implies that executive financial compensation explain $85.7 \%$ variation in DMBs situation awareness while the remaining $14.3 \%$ could be due to the influence of other factors not included in this study. The relationship is further tested applying t-statistics as shown in Table 6 below: 
Table 6: T-value result on executive financial compensation and situation awareness

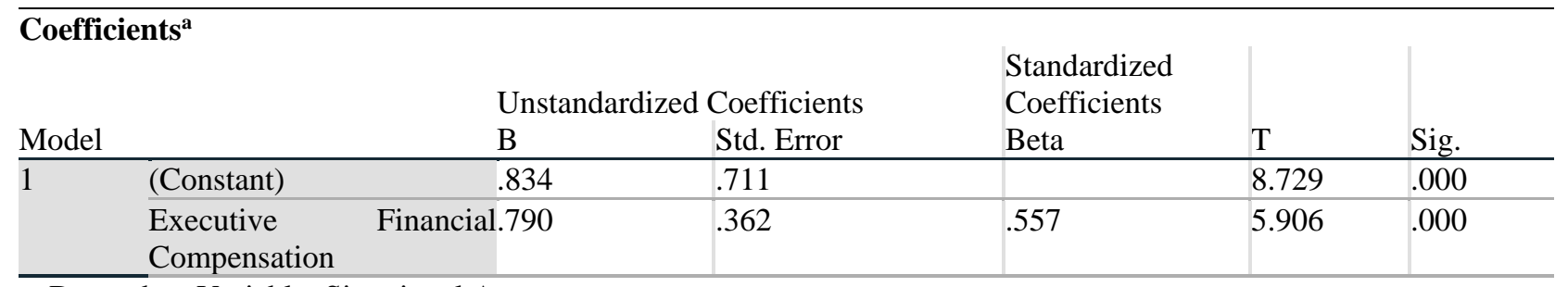

a. Dependent Variable: Situational Awareness

Source: SPSS v25: Output, 2020

From Table 4, the PV $=0.000$ which is less than 0.05 and Table 6 shows $\beta=0.790 ; \mathrm{t}$-cal. $=5.906>\mathrm{t}$-crit. $=1.96$ at $0.000<0.05 \%$ which means that the relationship between executive financial compensation and situation awareness is statistically significant. We therefore reject the null stated hypothesis and accept the alternate hypothesis, thus there is significant relationship between executive financial compensation and situation awareness of DMBs in Rivers State, Nigeria.

The Strength of the Relationship between Executive Financial Compensation and Innovation

Table 7: Correlation between executive financial compensation and innovation

\begin{tabular}{|c|c|c|c|c|}
\hline & & & $\begin{array}{l}\text { Executive } \\
\text { Financial } \\
\text { Compensation }\end{array}$ & Innovation \\
\hline \multirow[t]{6}{*}{ Spearman's rho } & Executive & FinancialCorrelation Coefficient & 1.000 & $.914^{* *}$ \\
\hline & Compensation & Sig. (2-tailed) & . & .000 \\
\hline & & $\mathrm{N}$ & 53 & 53 \\
\hline & Innovation & Correlation Coefficient & $.914^{* *}$ & 1.000 \\
\hline & & Sig. (2-tailed) & .000 & . \\
\hline & & $\mathrm{N}$ & 53 & 53 \\
\hline
\end{tabular}

**. Correlation is significant at the 0.05 level (2-tailed).

Source: SPSS v25: Output, 2020.

Table 7 reveals that a very strong and positive significant relationship exist between executive financial compensation and innovation with a $(r h o=0.914)$ and a PV $=0.000$ which is less than 0.05 . In other words positive relationship exists between the variables, thus, the provision of financial compensation to executives will motivate the executives to be innovative. The degree to which executive financial compensation influences innovation is further shown in the below table 8:

Table 8: the degree of effect of executive financial compensation on innovation

\begin{tabular}{|c|c|c|c|c|}
\hline \multicolumn{5}{|c|}{ Model Summary } \\
\hline Model & $\mathrm{R}$ & R Square & Adjusted R Square & Std. Error of the Estimate \\
\hline$\overline{1}$ & $.914^{\mathrm{a}}$ & .835 & .828 & .48115 \\
\hline
\end{tabular}

a. Predictors: (Constant), Executive Financial Compensation

Source: SPSS v25: Output, 2020

Table 8 above reveals the degree to which executive financial compensation influences executive innovation with R-val. $=0.914$ which implies a very strong relationship while the $\mathrm{R}^{2}=0.835$ implies that executive financial compensation explain $83.5 \%$ variation in DMBs innovation capability while the remaining $16.5 \%$ could be due to the influence of other factors not included in this study. The relationship is further tested applying t-statistics as shown in Table 9 below: 
Table 9: T-value result on executive financial compensation and innovation

\begin{tabular}{|c|c|c|c|c|c|c|}
\hline \multicolumn{7}{|c|}{ Coefficients $^{\mathbf{a}}$} \\
\hline \multirow{2}{*}{\multicolumn{2}{|c|}{ Model }} & \multicolumn{2}{|c|}{ Unstandardized Coefficients } & \multirow{2}{*}{$\begin{array}{l}\text { Standardized } \\
\text { Coefficients } \\
\text { Beta }\end{array}$} & \multirow[b]{2}{*}{$\mathrm{T}$} & \multirow[b]{2}{*}{ Sig. } \\
\hline & & $\mathrm{B}$ & Std. Error & & & \\
\hline$\overline{1}$ & (Constant) & .795 & .689 & & 13.807 & .000 \\
\hline & $\begin{array}{l}\text { Executive } \\
\text { Compensation }\end{array}$ & Financial.662 & .513 & .610 & 9.046 & .000 \\
\hline
\end{tabular}

a. Dependent Variable: Innovation

Source: SPSS v25: Output, 2020

From Table 7, the PV $=0.000$ which is less than 0.05 and Table 9 shows $\beta=0.662 ; \mathrm{t}$-cal. $=9.046>\mathrm{t}$-crit. $=1.96$ at $0.000<0.05 \%$ which means that the relationship between executive financial compensation and innovation is statistically significant. We therefore reject the null stated hypothesis and accept the alternate hypothesis, thus there is significant relationship between executive financial compensation and innovation of DMBs in Rivers State, Nigeria.

\section{DISCUSSION OF FINDINGS}

Based on the data analyzed, executive financial compensation has positive and significant relationship with organizational resilience vis-à-vis adaptive capacity, situational awareness and innovation. Sound compensation system is a hallmark of organizations success and prosperity. The success and stability of organization is measured with pay package provided to its employees including the executives. This is because, employees as well as executives' willingness to stay on the job largely depends on compensation packages of the organization (Armstrong, 2003). In other to ensure executive optimal performance and retention, organizations need to consider a variety of appropriate ways to rewarding them so as to achieve the desired results (Falola, Ibidunni \& Olokundun, 2014). Furthermore, executives as part of human resources in the organization facilitate seamless adaptation of organizations in everyday challenges and in a world of dynamic business environment. The presence of effective executive with requisite skills and knowledge was particularly highlighted by Beerman (2011) as a critical contributor to adaptive capacity. Thus, effective financial compensation will go a long way in providing motivation to the executives in trying to constantly modernize and integrate with partners, suppliers and customers to keep up with uncertain business environment and quickly reacting to customer demand, market opportunities and external threats.

Additionally, Tzu and Chung (2007) expressed that financial compensation given to the executives are used to improve their operational efficiency thereby motivating them to work harder in order to receive a high amount of future compensations depending on the productivity of the organization. This generally motivates executives to perform better. This can provide the executives the drive to provide the relationship necessary to facilitate the survival of the organization in its environment before, during and after crisis or challenges. More so, effective financial compensation provides executives the enthusiasm to manage organizational change through proper relationship with followers and encouraging them to innovate and to prepare for crisis (Goucher, 2007). Consequently, an ideal financial compensation system will positively impact on the efficiency and results produced by executives. It will encourage the executives to perform better and achieve the standards fixed, enhance the process of job evaluation, help in setting up an ideal job evaluation and the set standards would be more realistic and achievable.

Furthermore, financial compensations drive workers morale and the contribution of the rewards has existed in organizations especially in accordance with performance evaluation (Appelbaum, Schroeder, Cain \& Mitroff, 2011). All businesses organizations use salary, bonuses or other types of compensation to motivate and encourage high-level performance of their workforce including their executives which can provide a dynamic orientation to the situation at hand in the organization as well provide the opportunity to reflect not only the past, present and future, but the potential features of the situation. In motivating high executive performance, money is the fundamental inducement; no other motivation technique has been applied widely than pay due to its influential value (Tzu \& Chung, 2007). In the same vein, Kalim (2010) observed that money is a vital factor which affects employees' motivation. It is worthy to note that no human on earth does something if he or she lacks the motivation to doing it; he or she does anything as a result of either direct or indirect motivation, thus the motivation provided by financial compensation can provide the executives the ability to be at alert of what is happening around the organization, have understanding of what that information means to the organization now and in the future, anticipate opportunities and possible threats, disturbances and the ability to correctly identify potential crisis and their likely effects on the organization. Many organizations see financial compensation as a mediator to attract talented workers (executives), motivate and increase the retention rate of their workers to stay with the organization (Ahmad, Toh \& Bujang, 2013). Also, Riggio (2013) stated clearly that workers are motivated by money and material gains. This means that with fair 
and equitable financial compensation, executives are more likely to stay with the organization and gather the impetus to be aware of the happening around the organization and track events as they gradually unfold and makes appropriate decision that will affect the organization.

Innovation is crucial to organizational survival and growth in any industries especially in times of disruption. Innovation is important in the value-creating process of organizations and is a key determinant for firm growth (Lev, Nissim \& Thomas, 2008). Given the importance of innovation to the long-run success of business organizations, and given that executives reside at the strategic apexes of their organizations and make critical resource allocations pertaining to investments in new products and technologies, financially compensating the executives is a powerful mechanism for inducing them to pursue more valuable innovations (Balkin, Markman, \& Gomez-Mejia, 2000). With regards to innovation, Manso (2011) expressed that the executives are essential in guiding the organization to an optimal level of innovation in line with the organization's ultimate task of maximizing stakeholders' interest and in other to motivate innovation the organization should rely on compensation schemes. The main innovators in an organization are executives that contribute through their everyday work to the innovation capabilities of the organization (Lerner \& Wulf, 2007), thus good financial compensation will go a long way in motivating the executives towards bringing innovative ideas to the organization. Consequently, Ederer and Manso (2013) articulated that executives with good financial compensation are more likely to explore new options and discover new business strategies. In the same vein, Holmstrom (1989) suggests that the design of executive compensation is a significant determinant of the innovation produced by an organization.

\section{CONCLUSION}

Based on our findings, we therefore conclude that executive financial compensation positively and significantly affects organizational resilience vis-à-vis adaptive capacity, situation awareness and innovation of DMBs in Rivers State, Nigeria. Consequently, organizations of all types and sizes especially the DMBs may strengthen their resilience by engaging in a good, effective and efficient executive financial compensation. More so, sound executive financial compensation means having an environment that gives just and equitable compensation to executives for their works which serves as a means to motivating them to work harder to building an organization that will be able to withstand environmental changes.

\section{RECOMMENDATION}

1. DMBs that want to attain resilience should ensure their financial compensation plans include policies that provide comprehensible executives' compensation management.

2. DMBs should apply effective and efficient executive financial compensation to motivate their executives so as to withstand environmental threats.

\section{REFERENCES}

[1] Abdul, G. A. \& Syeda, Z. (2014). Impact of innovations on consumers' behaviour: a case study of Pak Electron Limited. European Journal of Business and Innovation Research, 2(6), 93-108.

[2] Ahmad, R., Toh, E. P. Y., \& Bujang, S. (2013). Relationship between types of benefit (leave, loan and retirement plan) and workers' retention. International journal of education and research, 1(8), 32-42

[3] Appelbaum, G., Schroeder, J. E., Cain, M.S. \& Mitroff, S.R. (2011) Improved visual cognition through stroboscopic training. Frontier Psychology, 2, 276-289.

[4] Armitage, D. (2005). Adaptive capacity and community-based natural resource management. Environmental Management, 35,703-715.

[5] Armstrong, M. (2003). A handbook of human resource management practice (9th ed.). Aberystwyth, Wales: Cambrian Printers Ltd.

[6] Balkin, D.B., Markman, G.D. \& Gomez-Mejia, L.R. (2000). Is CEO pay in high-technology firm related to innovation? Academy of Management Journal, 43(6), 1118-1129.

[7] Bebchuk, L., Grinstein, Y. \& Peyer, U. (2010). Lucky CEOs and lucky directors. Journal of Finance, 65(6), 2363-2401.

[8] Bedny, G. \& Meister, D. (1999). Theory of activity and situation awareness. International Journal of Cognitive Ergonomics, 3(1), 63-72.

[9] Beermann, M. (2011). Linking corporate climate adaptation strategies with resilience thinking. Journal of Clean Production, 19(8), 836-842.

[10] Damanpour, F. (1991). Organizational innovation: a meta-analysis of effects of determinants and moderators. Academy of Management Journal, 34 (3), 555-590.

[11] Dewald, J. \& Bowen, F. (2010). Storm clouds and silver linings: responding to disruptive innovations through cognitive resilience. Entrepreneurship Theory and Practice, 34 (1), 197-218.

[12] Ederer, F. \& Manso, G. (2013). Is pay for performance detrimental to innovation? Forth-coming: Management Science (http://dx.doi.org/10.1287/mnsc.1120.1683).

[13] Eketu, C.A. \& Ahiauzu, L.U. (2015). Product innovation and organizational resilience in South-South Nigeria. European Journal of Business and Management, 7(33), 24-43.

[14] Endsley, M. (1988). Design and evaluation for situational awareness enhancement proceedings of the human factors society. 32nd Annual Meeting, Santa Monica: HFES.

[15] Falola, H. O., Ibidunni, A.S, Olokundun, A. M. (2014). Incentives packages and employees' attitudes to work: a study of selected government parastatals in Ogun State, South-West, Nigeria. International Journal of Research in Business and Social Science, 3(1), 2147-4478.

[16] Gabriel, J. M. O. (2015). Organizational citizenship behaviour (OCB) and corporate resilience in the domestic aviation sector in Nigeria. A thesis submitted to Rivers State University of Science and Technology, Portharcourt, Rivers State.

[17] Goucher, N.P. (2007). Organizational knowledge creation to enhance adaptive capacity: exploratory, case studies in water resource management. London: Kogan-Page.

[18] Heatfield, S. (2018). How is executive compensation different from other employees? Retrieved from https://www.thebalancecareers.com/executivecompensation-1918119

[19] Holmstrom, B. (1989). Agency costs and innovation. Journal of Economic Behavior and Organization, 12(3), 69-81

[20] Jegede, C.A. (2012). Executive compensation structure, ownership and firm performance nexus: an empirical analysis. European Journal of Humanities and Social Science, 17(1), 882-888.

[21] Jensen, A. (2014). Is performance based pay practical for your company? Retrieved from http://www.andrewjensen.net/is-performance-based-paypractical-for your-company/

[22] Jensen, M.C. \& Meckling, W.H. (1997). Theory of the firm: managerial behaviour, agency costs and ownership structure. Journal of Financial Economics, 3, 305-360.

[23] Junaidu, M. K. \& Sanni, K. S. (2014) Executive compensation and financial performance of listed banks in Nigeria: an empirical analysis. Research Journal of Accounting, 2(3), 1-13. 
[24] Kalim, S.U. (2010). The relationship between rewards and employee motivation in commercial banks of Pakistan. Research Journal of International Studies, 14, 70-82.

[25] Lerner, J. \& Wulf, J. (2007). Innovation and incentives: evidence from corporate R\&D. The Review of Economics and Statistics, 89(4), 634-644.

[26] Lev, B., Nissim, D. \& Thomas, J. (2008). On the informational usefulness of r\&d capitalization and amortization. visualizing intangibles: measuring and reporting in the knowledge economy. Burlinton, VT: Ashgate Publishing.

[27] Madni, A.M (2007). Designing for resilience. ISTI Lecture Notes on Advanced Topics in Systems Engineering.

[28] Manso, G. (2011). Motivating innovation. Journal of Finance, 66(5), 1823 1860.

[29] Martocchio, J.J. (2004). Strategic compensation: a human resource management approach (3rd ed.). Upper Saddle River, New Jersey: Pearson, Prentice Hall.

[30] McManus, S., Seville, E., Vargo, J. \& Brundsdon, D. (2008). Facilitated process for improving organization resilience. Natural Hazards Review, 9(2), 81-90.

[31] Park, S., \& Sturman, M.C. (2009). The relative effect of merit pay, bonuses, ad long term incentives on future job performance. Retrieved from http://digitalcommons.ilr.cornell.edu/cri/7

[32] Riggio, R. E. (2013). Introduction to industrial: organizational psychology (6th ed.). New Jersey, US: Pearson Education.

[33] Robb, D. (2000). Building resilient organizations. Organizational Development, 32 (3), 27-32

[34] Seville, E., Porter, J. \& Askew, G. (2008). Enterprise resiliency: a sustainable growth imperative. Seoul, South Korea: AVESC (Aviation Security) World 2008, 11-13 Nov 2008. Access via UC Research Repository. (Conference Contributions - Full conference papers)

[35] Sheffi, Y. (2005). The resilient enterprise: overcoming vulnerability for competitive advantage. Cambridge: The MIT Press.
[36] Tella, A., Ayeni, C. O., \& Popoola, S. O. (2007). Work motivation, job satisfaction, and organizational commitment of library personnel in academic and research libraries in Oyo State, Nigeria. Retrieved from http://unllib.unl.edu/LPP/tella2.htm

[37] Tellis, G. J. (2013). Unrelenting Innovation: How to build a culture for market dominance. J-B Warren Bennis Series.

[38] Tzu, S.H., \& Chung, H.S. (2007). The effects of bonus systems on firm performance in Taiwan's high- tech sector. Journal of comparative economic, 35(1), 235-249.

[39] Umoh, G.I. Amah, E., \& Wokocha, H. I. (2014). Management development and organizational resilience. A case study of some selected manufacturing firms in Rivers state, Nigeria. IOSR Journal of Business and Management, 16(2), 07-16.

[40] Weick, K., Sutcliffe, B. \& Kathleen, M. (2007). Managing the unexpected: resilient performance in an age of uncertainty. San Francisco: Jossey-Bass.

[41] Wicker, P., Filo, K. \& Cuskelly, G. (2013). Organizational resilience of community sport clubs impacted by natural disasters. Journal of Sport Management, 5(12), 23-39.

\section{AUTHORS}

First Author - OGA, Kelechi Charles, PhD Student, Department of Management, Faculty of Management Sciences, University of Port Harcourt, Nigeria.

Second Author - EVWIERHURHOMA, Ejiroghene Daniel, PhD Student, Department of Management, Faculty of Management Sciences, University of Port Harcourt, Nigeria. 